\title{
Beneficial effects of carotenoid-producing cells of Bacillus indicus HU16 in a rat model of diet-induced metabolic syndrome
}

\author{
R. Crescenzo ${ }^{1 \#}$, A. Mazzoli ${ }^{1 \#}$, R. Cancelliere ${ }^{1}$, A. Bucci ${ }^{2}$, G. Naclerio $^{2}$, L. Baccigalupi ${ }^{1}$, S.M. Cutting ${ }^{3}$, E. Ricca ${ }^{1}$ \\ and S. Iossa $\mathbf{1}^{\text {* }}$ \\ ${ }^{1}$ Department of Biology, Federico II University, Via Cintia, 80126 Naples, Italy; ${ }^{2}$ Department of Biosciences and Territory, \\ University of Molise, Contrada Fonte Lappone, 86090 Pesche, Italy; ${ }^{3}$ School of Biological Sciences, Royal Holloway University \\ of London, Bourne Laboratories 4-26, Egham, Surrey TW20 OEX, United Kingdom; susiossa@unina.it; \#these authors \\ contributed equally to this work
}

Received: 22 February 2017 / Accepted: 8 May 2017

(c) 2017 Wageningen Academic Publishers

RESEARCH ARTICLE

\begin{abstract}
A well-established rat model of diet-induced metabolic syndrome was used to evaluate the effects of the oral administration of spores or cells of HU16, a carotenoid-producing strain of Bacillus indicus. Symptoms of metabolic syndrome were induced in 90-days old, male Sprague-Dawley rats maintained for eight weeks on a high-fat diet, as previously reported. Parallel groups of animals under the same diet regimen also received a daily dose of $1 \times 10^{10}$ cells or spores of $B$. indicus HU16. Cells of strain HU16 were able to reduce symptoms of metabolic syndrome, plasma markers of inflammation and oxidative markers in plasma and liver to levels similar to those observed in rats under a standard diet. HU16 cells did not affect obesity markers or the accumulation of triglycerides in the liver of treated animals. Denaturing gradient gel electrophoresis analysis showed that the oral administration of HU16 cells did not significantly affect the gut microbiota of high fat-fed rats, suggesting that the observed beneficial effects are not due to a reshaping of the gut microbiota but rather to metabolites produced by HU16 cells.
\end{abstract}

Keywords: insulin resistance, metabolic inflammation, Bacillus indicus HU16

\section{Introduction}

Diet plays an important role in the aetiology and prevention of the risk factors for the metabolic syndrome (O'Keefe et al., 2008; Salas-Salvadó et al., 2016). Many epidemiological studies have shown a strong inverse association between consumption of fruits and vegetables and the incidence of cardiovascular diseases (Bazzano et al., 2002; Crowe et al., 2011; Mirmiran et al., 2009). In addition, the intake of antioxidant phytochemicals has been associated with a reduction in the risk of type-2 diabetes (Cooper et al., 2012; Dembinska-Kiec et al., 2008; Hamer and Chida, 2007).

It is known that micronutrient antioxidants, such as vitamins and carotenoids, are decreased in both the serum and liver tissue of patients with chronic liver disease and cirrhosis (Leo et al., 1993; Ruhl and Everhart, 2003; Yadav et al., 2002). In addition, obesity is associated with low serum concentrations of carotenoids ( $\alpha$-carotene and $\beta$-carotene) and vitamin E (Gunanti et al., 2014; Neuhouser et al., 2001; Ruhl and Everhart, 2003). Thus, these micronutrient antioxidant deficiencies may also contribute to the development of greater adiposity and comorbidities, such as insulin resistance and hepatic steatosis. Importantly, carotenoids are as potent in inhibiting lipid peroxidation as vitamin $\mathrm{E}$ (Rock et al., 1996).

The potential health-promoting properties of carotenoids have led to a substantial interest in carotenoids as nutritional supplements, especially from natural sources. Carotenoidproducing bacteria have received interest in recent years due to the fact that many species are thought to be probiotics (Hempel et al., 2012; Ma et al., 2010) coupled with their ability to provide a suitable biosource of carotenoids with both C40 and C30 backbones (Perez-Fons et al., 2010) for the food and feed industry. In particular, spore-forming 
bacteria of the Bacillus genus have been reported to produce carotenoids with improved stability (Duc et al., 2006) and solubility (Sy et al., 2015). Although these bacteria are not photosynthetic organisms, several isolates produce carotenoids (Khaneja et al., 2010), that are essential for the cellular response to oxidative stress conditions (Manzo et al., 2011, 2013). Spore-forming bacteria share the ability to differentiate, producing a dormant spore, a highly resistant cell form able to survive harsh and extreme environmental conditions. Carotenoids are needed for the protection of cells but not of spores from reactive oxygen species (Manzo et al., 2013), however in some species including Bacillus indicus HU36, carotenoids have been found associated with both cells and spores (Duc et al., 2006).

We set out to investigate whether carotenoid-producing bacteria were able to counteract symptoms of metabolic syndrome induced in a rat model using a long-term dietary treatment with a high fat diet. To this aim we used $B$. indicus HU16, a previously characterised bacterium isolated from human faeces with a notable capacity to produce a yelloworange carotenoid (Khaneja et al., 2010).

\section{Methods}

\section{Bacterial growth, sporulation and spore purification}

B. indicus HU16 (Khaneja et al., 2010) was grown in LuriaBertani medium at $37^{\circ} \mathrm{C}$ in aerobic conditions. Cells were collected at the stationary phase of growth after $18 \mathrm{~h}$ of culture, washed two times and stored at $-20^{\circ} \mathrm{C}$. Sporulation was induced in Difco Sporulation (DS) medium (Difco, Detroit, MI, USA) by the exhaustion method (Cutting and Vander Horn, 1990). After a $48 \mathrm{~h}$ incubation at $37^{\circ} \mathrm{C}$, spores were collected, washed four times, purified by using overnight incubation in $\mathrm{H}_{2} \mathrm{O}$ at $4{ }^{\circ} \mathrm{C}$ to lyse residual sporangial cells (Nicholson and Setlow, 1990). To obtain the total number of cells and spores needed for the whole experimental period, various preparations were pulled together and counted using a cell counting chamber. $1 \mathrm{ml}$ aliquots, each containing $1 \times 10^{10}$ cells or spores suspended in a $10 \%(\mathrm{v} / \mathrm{v})$ sucrose solution, were immediately frozen and kept at $-20{ }^{\circ} \mathrm{C}$ until needed for the animal treatment.

\section{Animals and treatments}

Male Sprague-Dawley rats (90-days old; Charles River, Italy) were caged singly in a temperature-controlled room $\left(23 \pm 1{ }^{\circ} \mathrm{C}\right)$ with a $12 \mathrm{~h}$ light/dark cycle (06.3018.30). Treatment, housing and euthanasia of animals met the guidelines set by the Italian Health Ministry. All experimental procedures involving animals were approved by Comitato Etico-Scientifico per la Sperimentazione Animale of the University Federico II of Naples. Rats were fed either a standard low fat diet (Group 1, n=6) or a high fat diet $(n=18)$, previously reported to induce symptoms of metabolic syndrome and obesity (Crescenzo et al., 2008). The dietary treatment lasted eight weeks. The composition of the two diets is shown in Table 1.

Rats fed a high fat diet were subdivided into three groups (each composed of 6 rats), receiving each day by oral gavage $1 \mathrm{ml}$ of a $10 \%$ sucrose solution alone (Group 2) or containing $1 \times 10^{10}$ cells (Group 3 ) or $1 \times 10^{10}$ spores (Group 4) of $B$. indicus HU16 (Table 2).

During the treatments, body weight, food and water intake were monitored daily. Faeces were also collected daily and their energy content assessed with a bomb calorimeter, as previously reported (Crescenzo et al., 2010). At the end of the experimental period, the rats were euthanised by decapitation. Portal blood, systemic blood, caecum and

\section{Table 1. Composition of experimental diets.}

\begin{tabular}{|c|c|c|}
\hline & Low fat & High fat \\
\hline Standard chow ${ }^{1}, g$ & 49.98 & 49.98 \\
\hline Sunflower oil, g & 3.25 & 3.25 \\
\hline Casein, $g$ & 8.00 & 13.49 \\
\hline Butter, g & - & 19.49 \\
\hline Corn starch, g & 36.48 & 11.49 \\
\hline AIN Mineral $m^{2} x^{2}, g$ & 0.32 & 0.32 \\
\hline AIN Vitamin $m^{2} x^{2}, g$ & 0.13 & 0.13 \\
\hline Choline, g & 0.09 & 0.09 \\
\hline Methionine, $g$ & 0.64 & 0.64 \\
\hline Total weight, g & 100 & 100 \\
\hline Gross energy density, kJ/g & 18.9 & 22.6 \\
\hline $\begin{array}{l}\text { Metabolisable energy density }{ }^{3}, \mathrm{~kJ} / \mathrm{g} \\
\text { Macronutrient composition, } \%\end{array}$ & 13.6 & 18.0 \\
\hline Fat & 13 & 51 \\
\hline Carbohydrate & 66 & 28 \\
\hline Protein & 21 & 21 \\
\hline \multicolumn{3}{|c|}{$\begin{array}{l}{ }^{1} \text { Commercial non-purified diet (4 RF21, Mucedola, Italy) containing } \\
\text { (g/kg): protein } 185 \text {, lipid } 30 \text {, fibre } 60 \text {; metabolisable energy } 11.20 \mathrm{~kJ} / \mathrm{g} \text {. } \\
{ }^{2} \text { American Institute of Nutrition, } 1993 \text {. } \\
{ }^{3} \text { Estimated by computation using values }(\mathrm{kJ} / \mathrm{g}) \text { for energy content as } \\
\text { follows: protein } 16.736 \text {, lipid } 37.656 \text { and carbohydrate } 16.736 \text {. }\end{array}$} \\
\hline
\end{tabular}

Table 2. Treatments layout.

$\begin{array}{llllll} & \text { Group 1 } & \text { Group 2 } & \text { Group 3 } & \text { Group 4 } \\ \text { Diet } & \text { low fat } & \text { high fat } & \text { high fat } & \text { high fat } \\ & & & & \\ 10 \% \text { sucrose } & 0.5 \mathrm{ml} & 0.5 \mathrm{ml} & - & - \\ 10 \% \text { sucrose + cells } & - & - & 0.5 \mathrm{ml} & - \\ 10 \% \text { sucrose + spores } & - & - & - & 0.5 \mathrm{ml}\end{array}$


liver were collected, and the carcasses were used for body composition determination.

\section{Insulin tolerance test, glucose tolerance test, plasma metabolites}

Insulin tolerance tests (ITT) were carried out after 4 and 8 weeks of treatment. Rats were fasted for $6 \mathrm{~h}$ from 09:00 AM. Basal, post-absorptive blood samples were obtained from a small tail clip and placed in EDTA-coated tubes and then insulin ( $2.5 \mathrm{IU} / \mathrm{kg}$ body weight) was injected by the intraperitoneal route. Blood samples were collected after 20, 40, 60, 90 and $120 \mathrm{~min}$ and placed in EDTA-coated tubes. The blood samples were centrifuged at $1,400 \times g$ for $8 \mathrm{~min}$ at $4{ }^{\circ} \mathrm{C}$. Plasma glucose concentration was measured by colorimetric enzymatic method (Pokler Italia, Genova, Italy).

Glucose tolerance test (GTT) was carried out after 8 weeks of treatment. To this end, rats were fasted for $6 \mathrm{~h}$ from 09:00 AM. Basal, postabsorptive blood sample was obtained from a small tail clip and placed in EDTA-coated tubes and then glucose ( $2 \mathrm{~g} / \mathrm{kg}$ body weight) was injected intraperitoneally. Blood samples were collected after 20, 40, 60, 90 and $120 \mathrm{~min}$ and placed in EDTA-coated tubes. The blood samples were centrifuged at $1,400 \times g$ for $8 \mathrm{~min}$ at $4{ }^{\circ} \mathrm{C}$. Plasma glucose concentration was measured by colorimetric enzymatic method (Pokler Italia, Genova, Italy), while plasma insulin concentration was measured using an ELISA kit (Mercodia AB, Uppsala, Sweden) in a single assay to remove inter-assay variations.

Plasma concentrations of alanine aminotransferase, triglycerides, cholesterol and non-esterified fatty acids (NEFA) were measured using a colorimetric enzymatic method using commercial kits (SGM Italia, Rome, Italy). Lipid peroxidation was determined according to Fernandes et al. (2006), by measurement of thiobarbituric acid reactive substances (TBARS), using the thiobarbituric acid assay.

Plasma lipopolysaccharide (LPS) determinations were performed by a Limulus amaebocyte lysate (LAL) kit (Lonza, Basel, Switzerland) using a LAL extract according to the manufacturer's instruction. Briefly, samples were mixed with the LAL reagent and chromogenic substrate reagent for $16 \mathrm{~min}$ and absorbance readings were performed on a plate reader at $405 \mathrm{~nm}$. Tumour necrosis factor (TNF)- $\alpha$ concentrations in plasma samples were determined using a rat-specific enzyme linked immunosorbent assay (R\&D Systems, Minneapolis, MN, USA) according to the manufacturer's instruction.

\section{Body composition and energy balance}

After livers removal, guts were cleaned of undigested food and the carcasses were then autoclaved. After dilution in distilled water and subsequent homogenisation of the carcasses with a Polytron homogeniser (Kinematica, Luzern, Switzerland), duplicate samples of the homogenised carcasses were analysed for energy content using a bomb calorimeter. To take into account the energy content of liver, tissue samples were dried and the energy content was then measured with the bomb calorimeter. Total body water content was determined by drying carcass samples in an oven at $70^{\circ} \mathrm{C}$ for $48 \mathrm{~h}$. Total body lipids were measured by the Folch extraction method (Folch et al., 1957). Energy balance measurements were conducted by the comparative carcass technique over the experimental period, as detailed previously (Crescenzo et al., 2010).

\section{Liver composition, hepatic and mitochondrial oxidative stress}

Liver triglycerides and TBARS were measured as described above for plasma samples. Isolation of liver mitochondria was carried out as previously reported (Crescenzo et al., 2014). Lipid peroxidation was determined in isolated mitochondria by using the same procedure used for plasma samples.

\section{PCR-DGGE analysis}

Bacterial 16S rDNA fragments were amplified using nested PCR. For the primary amplification, PCR was conducted with the primers $27 \mathrm{~F}$ and 1492R (Chong et al., 2009). The PCR mixtures contained $5 \mu \mathrm{l}$ of extracted nucleic acids, $0.5 \mu \mathrm{M}$ of each primer, $250 \mu \mathrm{M}$ of each type of deoxyribonucleotide triphosphate, $10 \mu$ of $5 \times$ GoTaq $^{\oplus}$ Flexi Buffer, $1.25 \mathrm{U}^{\text {GoTaq }}{ }^{\oplus}$ DNA polymerase, $1.5 \mathrm{mM}$ $\mathrm{MgCl}_{2}$ (Promega Corporation, Madison, WI, USA) and sterile MilliQ water for a final volume of $50 \mu \mathrm{l}$. PCR amplification was performed using the following program: $95{ }^{\circ} \mathrm{C}$ for $2 \mathrm{~min}, 20$ cycles of denaturation at $92{ }^{\circ} \mathrm{C}$ for $45 \mathrm{~s}$, annealing at $50{ }^{\circ} \mathrm{C}$ for $2 \mathrm{~min}$, and extension at $72{ }^{\circ} \mathrm{C}$ for $1 \mathrm{~min}$ and $45 \mathrm{~s}$, and a single final extension at $72{ }^{\circ} \mathrm{C}$ for $5 \mathrm{~min}$. For the secondary amplification, the primer pair 341F-GC (with 40 bp GC-clamp) and 907R (Chong et al., 2009) was used. The reaction mixtures consisted of $2 \mu \mathrm{l}$ of template, $0.5 \mu \mathrm{M}$ of each primer, $400 \mu \mathrm{M}$ of each deoxyribonucleotide triphosphate, $10 \mu \mathrm{l}$ of $5 \times \mathrm{GoTaq}^{\oplus}$ Flexi Buffer, 1.25U GoTaq ${ }^{\circledR}$ DNA Polymerase, $1.5 \mathrm{mM} \mathrm{MgCl}_{2}$ (Promega Corporation) and sterile MilliQ water for a final volume of $50 \mu \mathrm{l}$. Touchdown PCR was performed with an initial denaturation step of $94^{\circ} \mathrm{C}$ for 5 min, 10 touchdown cycles of $94^{\circ} \mathrm{C}$ for $1 \mathrm{~min}, 65^{\circ} \mathrm{C}\left(-1^{\circ} \mathrm{C}\right.$ per cycle) for $1 \mathrm{~min}$ and $72{ }^{\circ} \mathrm{C}$ for $3 \mathrm{~min}, 5$ cycles of $94{ }^{\circ} \mathrm{C}$ for $1 \mathrm{~min}, 55^{\circ} \mathrm{C}$ for 1 min and $72^{\circ} \mathrm{C}$ for $2 \mathrm{~min}$, and a final elongation step of $72^{\circ} \mathrm{C}$ for $4 \mathrm{~min}$. The presence of PCR products was confirmed by analysing $5 \mu \mathrm{l}$ of product on $1.5 \%$ agarose gels and staining with ethidium bromide.

Denaturing gradient gel electrophoresis (DGGE) was performed with the BIO-RAD DCode ${ }^{\text {Ts }}$ Universal Mutation 
Detection System. PCR samples were loaded onto 7\% (w/v) polyacrylamide gels in $1 \times$ TAE (40 mM Tris base, $20 \mathrm{mM}$ acetic acid, glacial, $1 \mathrm{mM}$ EDTA [pH 8.0]). The 7\% (w/v) polyacrylamide gels (acrylamide/Bis solution, 37.5:1; BIO-RAD Laboratories, Inc., Hercules, CA, USA) were made with denaturing gradients ranging from $35 \%$ to $60 \%$ (where the $100 \%$ denaturant contains $7 \mathrm{M}$ of urea and $40 \%$ deionised formamide). The electrophoresis was performed at $60{ }^{\circ} \mathrm{C}$ for $16 \mathrm{~h}$ at $70 \mathrm{~V}$. After electrophoresis, the gels were soaked for $15 \mathrm{~min}$ in $250 \mathrm{ml}$ of $1 \times$ TAE running buffer and $0.5 \mu \mathrm{g} / \mathrm{ml}$ ethidium bromide, rinsed for $15 \mathrm{~min}$ in $250 \mathrm{ml}$ of $1 \times$ TAE running buffer and photographed.

DGGE patterns were analysed using the FPQuest Software Version 5.1 (BIO-RAD Laboratories, Inc.) to generate a band-matching table. All bands are divided into classes of common bands and for each pattern a particular band class can have two states: present or absent (binary matrix). The binary matrix obtained was exported to perform the Principal Component Analysis (PCA) with the PAST software (Hammer et al., 2001).

\section{Statistical analysis}

Data are reported as means with their standard errors (SEM). Statistical analyses were performed by one way ANOVA followed by the Tukey post-test. The MannWhitney U-test was applied to the PCA scores in order to evaluate the effect of the oral administration of a daily dose of $1 \times 10^{10}$ cells of $B$. indicus HU16 on gut microbiota of rats under a high fat diet. Probability values less than 0.05 were considered to indicate a significant difference. All analyses were performed using GraphPad Prism 6 (GraphPad Software, San Diego, CA, USA).

\section{Materials}

All chemicals used were of analytical grade and were purchased from Sigma-Aldrich (St. Louis, MO, USA).

\section{Results}

\section{Cells but not spores of Bacillus indicus HU16 rescued early signs of diet-induced metabolic syndrome}

After 4 weeks of dietary treatment, insulin tolerance tests were carried out to screen the efficacy of the treatment with spores or cells. The cumulative change in plasma glucose after insulin injection assessed through the measurement of area under the curve indicated that after 4 weeks of dietary treatment, high fat fed rats had already developed insulin resistance (Figure 1). The same effect was evident also in high fat fed rats treated with HU16 spores, while those that had received HU16 cells exhibited a glucose response to insulin very similar to that of low fat fed rats and were, therefore, protected by the diet-induced insulin resistance (Figure 1).

Since only cell-treated rats showed an improvement in glucose homeostasis compared to high fat fed rats, the dietary treatment was continued up to 8 weeks only for low fat-fed (Group 1), high fat-fed (Group 2) and high fat-fed rats receiving $B$. indicus cells (Group 3 ).

\section{Cells of Bacillus indicus HU16 did not affect obesity markers}

High fat dietary consumption sustained the development of diet-induced obesity, as shown by: (1) the significant increase in body weight and body lipids, with a concomitant decrease in body water (Table 3); (2) the altered plasma lipid profile, with a significant increase in triglycerides, cholesterol and NEFA (Table 4); and (3) the increased deposition of triglycerides in the liver (Table 4). All these obesity markers were not affected by the daily treatment with $1 \times 10^{10}$ cells of $B$. indicus HU16 (Table 3 and 4).
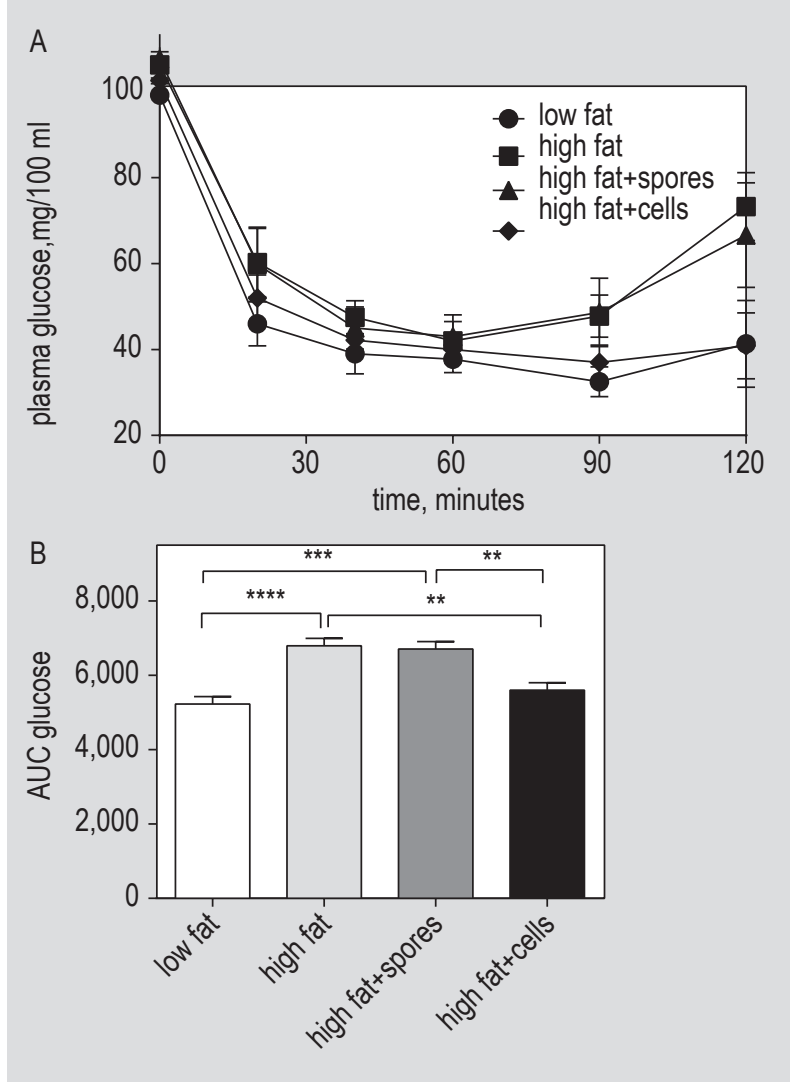

Figure 1. Plasma glucose levels $(\mathrm{A})$ and area under the curve (AUC, B) during insulin tolerance test after 4 weeks of dietary treatment in rats fed low fat diet, high fat diet, high fat diet + spores and high fat diet + cells. Values are reported as mean values \pm standard error of the mean; $n=6$ different rats. ** $P<0.01$, ${ }^{* * *} P<0.001$, **** $P<0.0001$ (one-way ANOVA followed by Tukey post-test). 
Table 3. Body composition and energy balance. ${ }^{1}$

\begin{tabular}{|c|c|c|c|}
\hline & Low fat & High fat & $\begin{array}{l}\text { High fat + } \\
\text { cells }\end{array}$ \\
\hline Initial body weight, g & $475 \pm 19$ & $473 \pm 15$ & $478 \pm 15$ \\
\hline Final body weight, g & $561 \pm 16$ & $599 \pm 12^{*}$ & $606 \pm 13^{*}$ \\
\hline Body weight gain, $g$ & $86 \pm 5$ & $126 \pm 12^{*}$ & $128 \pm 14^{*}$ \\
\hline Body lipids, g/100 g bw & $13.9 \pm 0.9$ & $17.0 \pm 1.4^{*}$ & $18.6 \pm 1.3^{*}$ \\
\hline Body proteins, $\mathrm{g} / 100 \mathrm{~g} \mathrm{bw}$ & $18.3 \pm 2.4$ & $18.5 \pm 0.8$ & $18.4 \pm 2.6$ \\
\hline Body water, g/100 g bw & $62.4 \pm 0.8$ & $59.4 \pm 1.1^{*}$ & $57.2 \pm 1.8^{*}$ \\
\hline $\begin{array}{l}\text { Epidydimal adipose tissue, } \\
\mathrm{mg} / \mathrm{g} \mathrm{bw}\end{array}$ & $16 \pm 1$ & $22 \pm 2^{*}$ & $22 \pm 2^{*}$ \\
\hline Body energy, $\mathrm{kJ} / \mathrm{g}$ & $9.8 \pm 0.2$ & $11.1 \pm 0.4^{*}$ & $11.6 \pm 0.3^{*}$ \\
\hline $\begin{array}{l}\text { Metabolisable energy } \\
\text { intake, kJ }\end{array}$ & $11,931 \pm 189$ & $12,278 \pm 355$ & $12,099 \pm 287$ \\
\hline Energy gain, kJ & $1,473 \pm 89$ & $2,615 \pm 367^{*}$ & $2,704 \pm 125^{*}$ \\
\hline Lipid gain, kJ & $1,164 \pm 190$ & $2,307 \pm 349^{*}$ & $2,310 \pm 215^{*}$ \\
\hline Protein gain, kJ & $298 \pm 10$ & $329 \pm 28$ & $300 \pm 15$ \\
\hline Energy expenditure, $\mathrm{kJ}$ & $10,558 \pm 241$ & $9,463 \pm 392$ & $9,480 \pm 250$ \\
\hline
\end{tabular}

Table 4. Plasma and liver parameters. ${ }^{1,2}$

\begin{tabular}{|c|c|c|c|}
\hline & Low fat & High fat & $\begin{array}{l}\text { High fat + } \\
\text { cells }\end{array}$ \\
\hline $\begin{array}{l}\text { Plasma triglycerides, } \\
\text { mg/100 ml }\end{array}$ & $97.6 \pm 5$ & $204.2 \pm 10^{*}$ & $193.0 \pm 12^{*}$ \\
\hline $\begin{array}{l}\text { Plasma cholesterol, } \\
\mathrm{mg} / 100 \mathrm{ml}\end{array}$ & $57.1 \pm 2$ & $105.9 \pm 10^{*}$ & $93.1 \pm 5^{*}$ \\
\hline $\begin{array}{l}\text { Plasma non esterified fatty } \\
\text { acids, } \mathrm{mM}\end{array}$ & $0.39 \pm 0.02$ & $0.50 \pm 0.02^{*}$ & $0.46 \pm 0.02^{*}$ \\
\hline $\begin{array}{l}\text { Plasma lipid peroxidation, } \\
\text { nmol TBARS/ml }\end{array}$ & $2.1 \pm 0.2$ & $3.8 \pm 0.3^{*}$ & $2.8 \pm 0.2 \#$ \\
\hline Plasma ALT, U/I & $11.6 \pm 0.4$ & $28.1 \pm 1.0^{*}$ & $17.8 \pm 1.0^{*} \#$ \\
\hline Plasma LPS, EU/ml & $0.59 \pm 0.02$ & $1.76 \pm 0.2^{*}$ & $1.0 \pm 0.1 \#$ \\
\hline Plasma TNF-a, pg/ml & $23.5 \pm 1.8$ & $40.8 \pm 4.8^{*}$ & $25.5 \pm 1.7 \#$ \\
\hline $\begin{array}{l}\text { Hepatic triglycerides, } \\
\text { mg/g tissue }\end{array}$ & $10.2 \pm 2.3$ & $24.5 \pm 2.7^{*}$ & $22.9 \pm 2.7^{*}$ \\
\hline $\begin{array}{l}\text { Hepatic lipid peroxidation, } \\
\text { nmol TBARS/g tissue }\end{array}$ & $64.4 \pm 4.3$ & $79.8 \pm 1.9^{\star}$ & $68.6 \pm 2.6 \#$ \\
\hline $\begin{array}{l}\text { Hepatic mitochondrial } \\
\text { lipid peroxidation, } \\
\text { nmol TBARS/mg protein }\end{array}$ & $0.52 \pm 0.01$ & $0.60 \pm 0.02^{*}$ & $0.50 \pm 0.01 \#$ \\
\hline
\end{tabular}

${ }^{1}$ ALT = alanine aminotransferase; LPS = lipopolysaccharide; TBARS = thiobarbituric acid reactive substances; TNF = tumour necrosis factor.

${ }^{2}$ Values are reported as mean values \pm standard error of the mean; $n=6$ different rats. ${ }^{*} P<0.05$ compared to low fat, \# $P<0.05$ compared to high fat (one-way ANOVA followed by Tukey post-test).

\section{Cells of Bacillus indicus HU16 rescued signs of diet- induced metabolic syndrome and oxidative damage}

As previously reported (Crescenzo et al., 2008), at the end of the 8-week period, high fat fed rats exhibited whole body insulin resistance (Figure 2). In fact, the decrease in plasma glucose concentration induced by a given dose of insulin was lower, and the increase in plasma insulin induced by a given dose of glucose was higher, in high fat fed rats compared to low fat fed rats (Figure 2). In both tests, the treatment with $1 \times 10^{10}$ cells of $B$. indicus HU16 was protective against the development of insulin resistance (Figure 2).

Eight weeks of high fat diet also elicited a significant increase in systemic inflammation markers LPS and TNF- $\alpha$, as well as an increase in oxidative damage of plasma lipids and hepatic necrosis (Table 4). These metabolic derangements were prevented by the administration of a daily dose of $1 \times 10^{10}$ cells of $B$. indicus HU16 (Table 4). Oxidative stress was enhanced by eight weeks of high fat feeding in whole liver tissue and at the mitochondrial level (Table 4), but in this case the treatment of high fat fed rats with $1 \times 10^{10}$ cells of B. indicus HU16 was protective (Table 4).

\section{Eight weeks of treatment with HU16 cells did not affect the gut microbiota of high fat-fed rats}

The majority of the samples from high fat fed animals treated (Group 3, circles) or not treated (Group 2, diamonds) with HU16 cells clustered together, while samples from two rats of each group were arranged separately (Figure 3 ). The Mann-Whitney U test performed on the PCA scores did not identify any statistically significant difference between the two groups. Therefore, the DGGE analysis suggests that the oral administration of a daily dose of $1 \times 10^{10}$ cells of $B$. indicus HU16 did not affect the microbial composition of the animal gut.

\section{Discussion}

A high fat diet was used in the present study to mimic human diets that have been associated with the development of the metabolic syndrome. In fact, this diet induced changes in metabolic and hepatic functions, such as excessive abdominal fat deposition, impaired glucose tolerance and increased plasma lipid concentrations (Crescenzo et al., 2008), together with increased plasma oxidative stress markers and liver transaminase compared with low-fat diet fed rats. On this animal model, we tested the hypothesis that the administration of the carotenoidproducing bacterial strain $B$. indicus HU16 could reverse obesity and/or associated metabolic syndrome induced by long-term dietary treatment with a high fat diet. At variance with results obtained with marine carotenoid fucoxanthin (Gammone and D'Orazio, 2015), simultaneous 
A

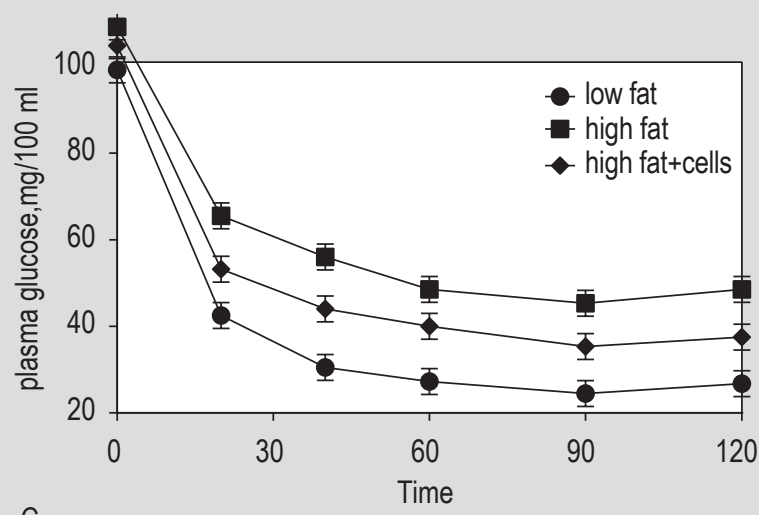

C

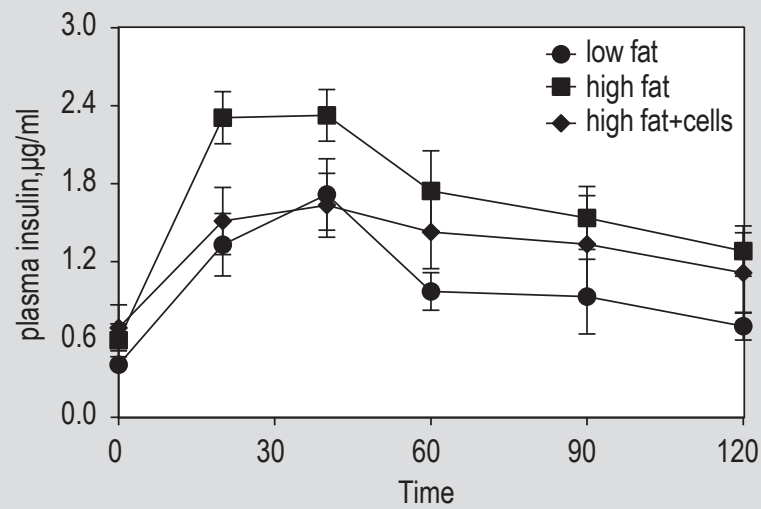

E

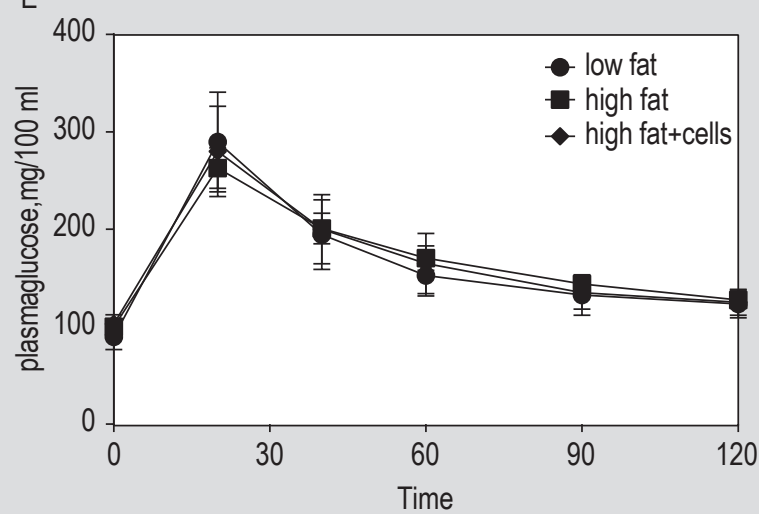

B

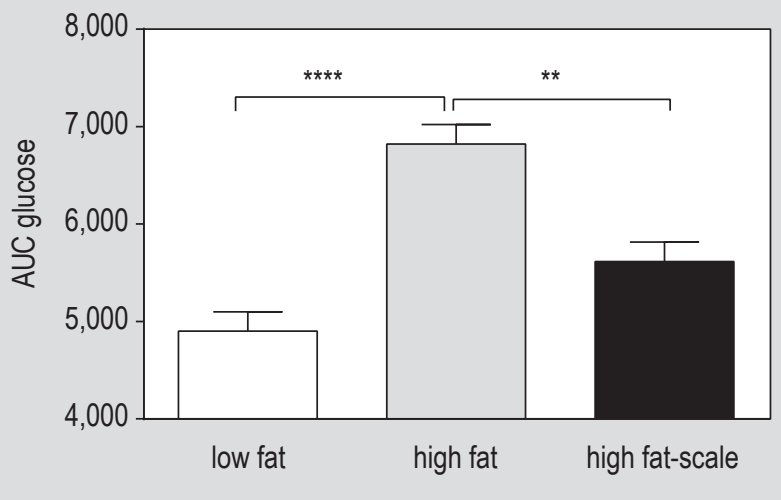

D

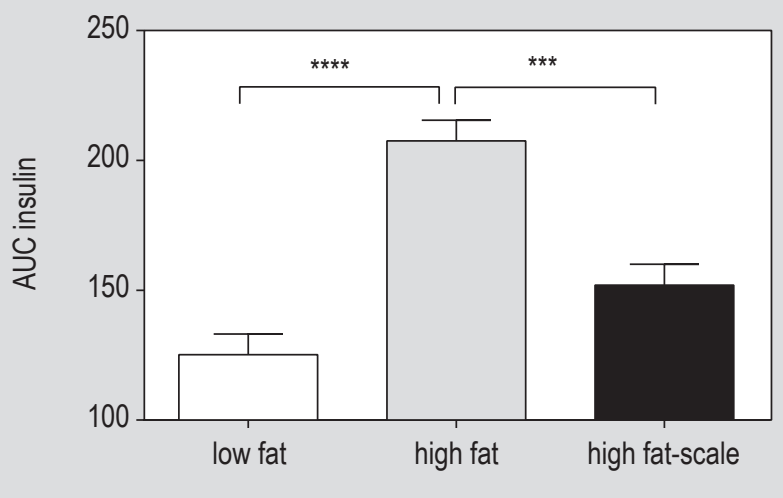

$\mathrm{F}$

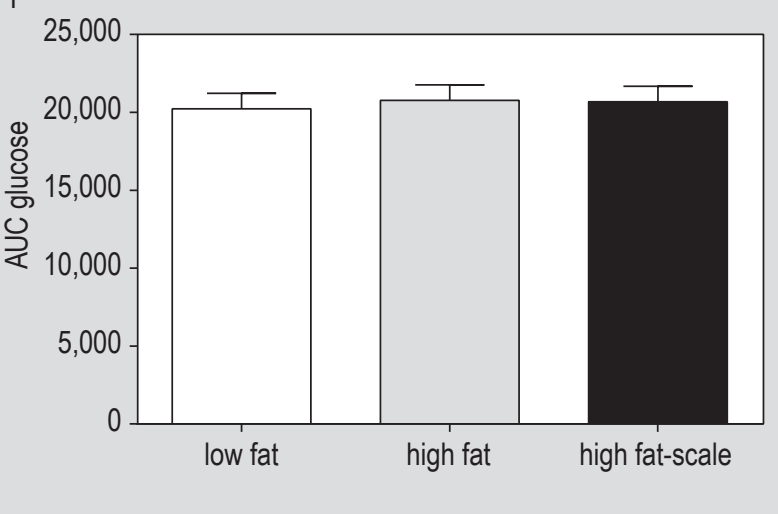

Figure 2. Plasma glucose levels (A) and area under the curve (AUC, B) during insulin tolerance test, plasma insulin levels (C) and area under the curve (AUC, D) during glucose tolerance test, plasma glucose levels $(E)$ and area under the curve (AUC, F) during glucose tolerance test, after 8 weeks of dietary treatment in rats fed low fat diet, high fat diet or high fat diet + cells. Values are reported as mean values \pm standard error of the mean; $n=6$ different rats. ${ }^{* *} P<0.01$, ${ }^{* * *} P<0.001,{ }^{* * * *} P<0.0001$ (one-way ANOVA followed by Tukey post-test).

administration of carotenoid-producing bacterial cells did not affect the development of high fat diet-induced obesity nor abolished the modifications of plasma lipid profile. Interestingly, however, the most relevant high fatassociated metabolic impairment, i.e. insulin resistance, was completely reversed by bacterial administration. In addition, although plasma lipids were increased in high fat fed rats receiving bacterial cells, this treatment abolished the increase in peroxidised lipids, suggesting that the condition of increased oxidative stress elicited by high fat diet is prevented by bacterial administration. This result is interesting, since oxidative stress is today considered a leading cause for the onset of obesity-associated insulin resistance (Bettaieb et al., 2014; Rains and Jain, 2011).

Obesity is also associated with metabolic endotoxemia and a proinflammatory state, that contribute to the metabolic derangement observed both in human and animals (Cani 


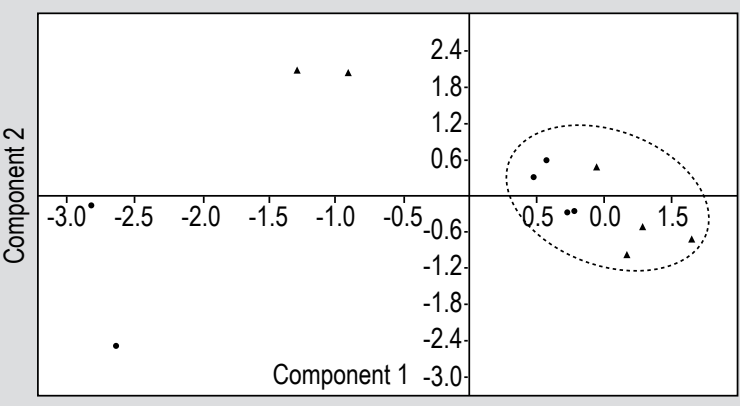

Figure 3. Principal component analysis score plot of PCR-DGGE patterns of gut microbiota of high fat-fed rats treated (black circles) and not treated (black triangles) with a daily dose of $1 \times 10^{10}$ cells of Bacillus indicus HU16.

et al., 2007; Di Luccia et al., 2015; Gomes et al., 2017). We therefore looked at this aspect in our experiments to verify whether bacterial administration could exert an influence on the above parameters and we found a protective effect of these bacteria with regard to metabolic endotoxemia and inflammation. In addition, bacteria also exerted a protective effect on liver necrosis and therefore we looked at liver function more in depth. One important and deleterious consequence of high fat feeding and obesity is the development of hepatic triglyceride deposition, that represents the first step on the way to the development of non-alcoholic steatohepatitis, the second step being represented by oxidative stress (Asrih and Jornayvaz, 2015). High fat diet resulted in the increased triglyceride deposition, accompanied by increased lipid peroxidation in the liver and plasma of rats. The administration of Bacillus bacteria prevented these adverse effects of high fat diet and appears to be protective against oxidative stress. Mitochondria are primary cellular sites of production of reactive oxygen species and we looked at the oxidative damage in these organelles. Hepatic mitochondria isolated from rats fed a high fat diet showed a high degree of oxidative stress, while in rats fed a high fat diet and supplemented with bacteria, the degree of oxidative stress was found to be identical to that of rats fed low fat diet, thus suggesting that bacterial supplementation exerts a protective role also on mitochondria.

It is well established that the diet is a main factor involved in shaping the microbial composition of the gut (De Filippo et al., 2010) and that a high fat diet alters the gut microbiota both in animal models (Di Luccia et al., 2015; Rabot et al., 2016) and in humans (Sonnenburg and Backed, 2016). Such alterations have been linked to the development of the metabolic syndrome and obesity (Murphy et al., 2015). We observed by DGGE analysis that the oral administration of a daily dose of $1 \times 10^{10}$ cells of $B$. indicus HU16 to high fat fed rats did not significantly alter the microbial composition of the gut. Although a metagenomic approach would be needed to completely rule out the possibility that HU16 cells had an effect on the gut microbiota, our DGGE analysis suggests that major alterations in the gut composition had not occurred. Based on this, we hypothesise that HU16 cells produce metabolites able to directly reduce the oxidative damages caused by the high fat diet. Because of the wellknown anti-oxidant activity of carotenoids, the carotenoids produced by HU16 cells are an obvious candidate. Verifying this hypothesis will require new in vivo experiments with the purified carotenoid and a HU16 mutant unable to produce the carotenoid and will be a challenging task for future work. An additional question raised by this work is why HU16 spores do not show any beneficial effect in our rat model of diet-induced metabolic syndrome. It has been elegantly demonstrated that $B$. subtilis spores once ingested can perform an entire life cycle in the mouse gastrointestinal tract, germinating in the upper part of the intestine, undergoing few rounds of growth and then sporulating the lower intestine (Casula and Cutting, 2002). A similar evidence is not currently available for either the rat gastrointestinal tract or the $B$. indicus spore. Therefore, we hypothesise that in the rat intestine HU16 spores either: (1) do not germinate; (2) germinate with a very low efficiency; or (3) that germinated spores are unable to grow. According to this hypothesis cells but not spores have a beneficial, probiotic role. Further work will be needed to address this hypothesis.

\section{Acknowledgements}

This work was supported by a grant from University of Napoli 'Federico II' and by Progetto ASI (Agenzia Spaziale Italiana) N. 2015-008-R.0.

\section{References}

Asrih, M. and Jornayvaz, F.R., 2015. Metabolic syndrome and nonalcoholic fatty liver disease: is insulin resistance the link? Molecular and Cellular Endocrinology 418: 55-65.

Bazzano, L.A., He, J. and Ogden, L.G., 2002. Fruit and vegetable intake and risk of cardiovascular disease in US adults: the first National Health and Nutrition Examination Survey Epidemiologic Follow-up Study. American Journal of Clinical Nutrition 76: 93-99.

Bettaieb, A., Vazquez Prieto, M.A., Rodriguez Lanzi, C., Miatello, R.M., Haj, F.G., Fraga, C.G. and Oteiza, P.I., 2014. (-)-Epicatechin mitigates high-fructose-associated insulin resistance by modulating redox signaling and endoplasmic reticulum stress. Free Radical Biology and Medicine 72: 247-256.

Cani, P.D., Amar, J., Iglesias, M.A., Poggi, M., Knauf, C., Bastelica, D., Neyrinck, A.M., Fava, F., Tuohy, K.M., Chabo, C., Waget, A., Delmée, E., Cousin, B., Sulpice, T., Chamontin, B., Ferrières, J., Tanti, J.F., Gibson, G.R.,Casteilla, L., Delzenne, N.M., Alessi, M.C. and Burcelin, R., 2007. Metabolic endotoxemia initiates obesity and insulin resistance. Diabetes 56: 1761-1772. 
Casula, G. and Cutting, S.M., 2002. Bacillus probiotics: spore germination in the gastrointestinal tract. Applied and Environmental Microbiology 68: 2344-2352.

Chong, C.W., Dunn, M.J., Convey, P., Tan, G.Y.A., Wong, R.C.S. and Tan, I.K.P., 2009. Environmental influences on bacterial diversity of soils on Signy Island, maritime Antarctic. Polar Biology 32: 1571-1582.

Cooper, A.J., Forouhi, N.G., Ye, Z., Buijsse, B., Arriola, L., Balkau, B., Barricarte, A., Beulens, J.W., Boeing, H., Büchner, F.L., Dahm, C.C., De Lauzon-Guillain, B., Fagherazzi, G., Franks, P.W., Gonzalez, C., Grioni, S., Kaaks, R., Key, T.J., Masala, G., Navarro, C., Nilsson, P., Overvad, K., Panico, S., Ramón Quirós, J., Rolandsson, O., Roswall, N., Sacerdote, C., Sánchez, M.J., Slimani, N., Sluijs, I., Spijkerman, A.M., Teucher, B., Tjonneland, A., Tumino, R., Sharp, S.J., Langenberg, C., Feskens, E.J., Riboli, E., Wareham, N.J. and InterAct Consortium., 2012. Fruit and vegetable intake and type 2 diabetes: EPIC-InterAct prospective study and meta-analysis. European Journal of Clinical Nutrition 66: 1082-1092.

Crescenzo, R., Bianco, F., Coppola, P., Mazzoli, A., Tussellino, M., Carotenuto, R., Liverini, G. and Iossa, S., 2014. Fructose supplementation worsens the deleterious effect of short-term highfat feeding on hepatic steatosis and lipid metabolism in adult rats. Experimental Physiology 99: 1203-1213.

Crescenzo, R., Bianco, F., Falcone, I., Prisco, M., Dulloo, A.G., Liverini, G. and Iossa, S., 2010. Hepatic mitchondrial energetics during catch-up fat after caloric restriction. Metabolism 59: 1221-1230.

Crescenzo, R., Bianco, F., Falcone, I., Prisco, M., Liverini, G. and Iossa, S., 2008. Alterations in hepatic mitochondrial compartment in a model of obesity and insulin resistance. Obesity 16: 958-964.

Crowe, F.L., Roddam, A.W., Key, T.J., Appleby, P.N., Overvad, K., Jakobsen, M.U., Tjønneland, A., Hansen, L., Boeing, H., Weikert, C., Linseisen, J., Kaaks, R., Trichopoulou, A., Misirli, G., Lagiou, P., Sacerdote, C., Pala, V., Palli, D., Tumino, R., Panico, S., Bueno-deMesquita, H.B., Boer, J., Van Gils, C.H., Beulens, J.W., Barricarte, A., Rodríguez, L., Larrañaga, N., Sánchez, M.J., Tormo, M.J., Buckland, G., Lund, E., Hedblad, B., Melander, O., Jansson, J.H., Wennberg, P., Wareham, N.J., Slimani, N., Romieu, I., Jenab, M., Danesh, J., Gallo, V., Norat, T., Riboli, E. and European Prospective Investigation into Cancer and Nutrition (EPIC)-Heart Study Collaborators, 2011. Fruit and vegetable intake and mortality from ischaemic heart disease: results from the European Prospective Investigation into Cancer and Nutrition (EPIC)-Heart study. European Heart Journal 32: $1235-1243$.

Cutting, S. and Vander Horn, P.B., 1990. Genetic analysis. In: Harwood, C. and Cutting, S. (eds.) Molecular biological methods for Bacillus. John Wiley and Sons, Chichester, UK, pp. 27-74.

De Filippo, C., Cavalieri, D., Di Paola, M., Ramazzotti, M., Poullet, J.B., Massart, S., Collini, S., Pieraccini, G. and Lionetti, P., 2010. Impact of diet in shaping gut microbiota revealed by a comparative study in children from Europe and rural Africa. Proceedings of the National Academy of Sciences of the USA 107: 14691-14696.

Dembinska-Kiec, A., Mykkanen, O., Kiec-Wilk, B. and Mykkänen, H., 2008. Antioxidant phytochemicals against type 2 diabetes. British Journal of Nutrition 99: ES109-ES117.
Di Luccia, B., Crescenzo, R., Mazzoli, A., Cigliano, L., Venditti, P., Walser, J.C., Widmer, A., Baccigalupi, L., Ricca, E. and Iossa, S., 2015. Rescue of fructose-induced metabolic syndrome by antibiotics or faecal transplantation in a rat model of obesity. PLoS ONE 10: e0134893.

Duc, L.H., Fraser, P., Tam, N.K.M. and Cutting, S.M., 2006. Carotenoids present in halotolerant Bacillus spore formers. FEMS Microbiology Letters 255: 215-224.

Fernandes, M.A., Custódio, J.B., Santos, M.S., Moreno, A.J. and Vicente, J.A., 2006. Tetrandrine concentrations not affecting oxidative phosphorylation protect rat liver mitochondria from oxidative stress. Mitochondrion 6: 176-185.

Folch, J., Lees, M. and Stanley, G.H.S., 1957. A simple method for the isolation and purification of total lipids from animal tissues. Journal of Biological Chemistry 226: 497-510.

Gammone, M.A. and D'Orazio, N., 2015. Anti-obesity activity of the marine carotenoid fucoxanthin. Marine Drugs 13: 2196-2214.

Gomes, J.M.G., De Assis Costa, J. and De Cássia Gonçalves Alfenas, R., 2017. Metabolic endotoxemia and diabetes mellitus: a systematic review. Metabolism 68: 133-144.

Gunanti, I.R., Marks, G.C., Al-Mamun, A. and Long, K.Z., 2014. Low serum concentrations of carotenoids and vitamin $\mathrm{E}$ are associated with high adiposity in Mexican-American children. Journal of Nutrition 144: 489-495.

Hamer, M. and Chida, Y., 2007. Intake of fruit, vegetables, and antioxidants and risk of type 2 diabetes: systematic review and meta-analysis. Journal of Hypertension 25: 2361-2369.

Hammer, Ø., Harper, D.A.T. and Ryan, P.D., 2001. PAST: paleontological statistics software package for education and data analysis. Palaeontologia Electronica 4: 9.

Hempel, S., Newberry, S.J., Maher, A.R., Wang, Z., Miles, J.N., Shanman, R., Johnsen, B. and Shekelle, P.G., 2012. Probiotics for the prevention and treatment of antibiotic-associated diarrhea: a systematic review and meta-analysis. Journal of the American Medical Association 307: 1959-1969.

Khaneja, R., Perez-Fons, L., Fakhry, S., Baccigalupi, L., Steiger, S., To, E., Sandmann, G., Dong, T.G., Ricca, E., Fraser, P.D. and Cutting, S.M., 2010. Carotenoids found in Bacillus. Journal of Applied Microbiology 108: 1889-1902.

Leo, M.A., Rosman, A.S. and Lieber, C.S., 1993. Differential depletion of carotenoids and tocopherol in liver disease. Hepatology 17: 977-986.

Ma, E.L., Choi, Y.J., Choi, J., Pothoulakis, C., Rhee, S.H. and Im, E., 2010. The anticancer effect of probiotic Bacillus polyfermenticus on human colon cancer cells is mediated through ErbB2 and ErbB3 inhibition. International Journal of Cancer 127: 780-790.

Manzo, N., D’Apuzzo, E., Coutinho, P.M., Cutting, S.M., Henrissat, B. and Ricca, E., 2011. Carbohydrate-active enzymes from pigmented Bacilli: a genomic approach to assess carbohydrate utilization and degradation. BioMedCentral Microbiology 11: 198.

Manzo, N., Di Luccia, B., Isticato, R., D’Apuzzo, E., De Felice, M. and Ricca, E., 2013. Pigmentation and sporulation are alternative cell fates in Bacillus pumilus SF214. PLoS ONE 8: e62093.

Mirmiran, P., Noori, N., Zavareh, M.B. and Azizi, F., 2009. Fruit and vegetable consumption and risk factors for cardiovascular disease. Metabolism 58: 460-468. 
Murphy, E.A., Velazquez, K.T. and Herbert, K.M., 2015. Influence of high-fat-diet on gut microbiota: a driving force for chronic disease risk. Current Opinion in Clinical Nutrition and Metabolic Care 18: 515-520.

Neuhouser, M.L., Rock, C.L., Eldridge, A.L., Kristal, A.R., Patterson, R.E., Cooper, D.A., Neumark-Sztainer, D., Cheskin, L.J. and Thornquist, M.D., 2001. Serum concentrations of retinol, $\alpha$-tocopherol and the carotenoids are influenced by diet, race and obesity in a sample of healthy adolescents. Journal of Nutrition 131: 2184-2191.

Nicholson, W.L. and Setlow, P., 1990. Sporulation, germination and outgrowth. In: Harwood, C. and Cutting, S. (eds.) Molecular biological methods for Bacillus. John Wiley and Sons, Chichester, UK, pp. 391-450.

O'Keefe, J.H., Gheewala, N.M. and O'Keefe, J.O., 2008. Dietary strategies for improving post-prandial glucose, lipids, inflammation, and cardiovascular health. Journal of the American College of Cardiology 51: 249-255.

Perez-Fons, L., Steiger, S., Khaneja, R., Bramley, P.M., Cutting, S.M., Sandmann, G. and Fraser, P.D., 2010. Identification and the developmental formation of carotenoid pigments in the yellow/ orange Bacillus spore-formers. Biochimica et Biophysica Acta 1811: 177-185.

Rabot, S., Membrez, M., Blancher, F., Berger, B., Moine, D., Krause, L., Bibiloni, R., Bruneau, A., Gerard, P., Lauber, C.L. and Chou, C.J., 2016. High fat diet drives obesity regardless the composition of gut microbiota in mice. Scientific Reports 6: 32484.
Rains, J.L. and Jain, S.K., 2011. Oxidative stress, insulin signaling, and diabetes. Free Radical Biology and Medicine 50: 567-575.

Rock, C.L., Jacob, R.A. and Bowen, P.E., 1996. Update on the biological characteristics of the antioxidant micronutrients: vitamin $\mathrm{C}$, vitamin $\mathrm{E}$, and the carotenoids. Journal of the American Diet Association 96: 693-702.

Ruhl, C.E. and Everhart, J.E., 2003. Relation of elevated serum alanine aminotransferase activity with iron and antioxidant levels in the United States. Gastroenterology 124: 1821-1829.

Salas-Salvadó, J., Guasch-Ferré, M., Lee, C.H., Estruch, R., Clish, C.B. and Ros, E., 2016. Protective effects of the mediterranean diet on Type 2 Diabetes and metabolic syndrome. Journal of Nutrition 146: 920S-927S.

Sonnenburg, J.L. and Backhed, F., 2016. Diet-microbiota interactions as moderators of human metabolism. Nature 535: 56-64.

Sy, C., Dangles, O., Borel, P. and Caris-Veyrat, C., 2015. Interactions between Carotenoids from marine bacteria and other micronutrients: impact on stability and antioxidant activity. Marine Drugs 13: 7020-7039.

Yadav, D., Hertan, H.I., Schweitzer, P., Norkus, E.P. and Pitchumoni, C.S., 2002. Serum and liver micronutrient antioxidants and serum oxidative stress in patients with chronic hepatitis C. American Journal of Gastroenterology 97: 2634-2639. 
